\title{
Insight on Infectious Diseases from the Perspective of One Health
}

\author{
Zhongwei Jia ${ }^{1,2,3, *}$
}

Pathogenic organisms, animals, and humans have always existed in the same ecosystem, but people rarely think of this when they are engaged in specific research regarding human health. However, people often argue on which of heredity or environment is more important to human health, and they never doubt the importance of environments on health. The unifying concepts of One Health are not entirely new as it has reemerged and been recognized again in recent years. One Health was formally endorsed by 3 bodies of the United Nations in 2010 including the Food and Agriculture Organization (FAO), the World Organization for Animal Health (OIE), and the World Health Organization (WHO) (1). Moreover, November 3 has been designated as One Health Day in 2016 (2).

In one ecosystem, whether disease-causing pathogens can successfully invade humans is dominated by genetics and the ecological environment, which is a complex interaction. One Health is an approach that recognizes that the health of people is closely connected to the health of animals and to the health of the environment, which provides an opportunity for people to work on one thing together (3). Coronavirus disease 2019 (COVID-19) is not the last pandemic which humans are co-infected with other animal species, and yet human beings cannot solve all health problems between humans, animals, and the environment in a short time. Conversely, it is more likely for human to struggle with new health problems all the time. But, COVID-19 makes people realize the importance of uniting against infectious diseases and further realize the importance of One Health.

Everyone has a role to play on earth. Collaboration and coordination among experts working in animal, human, and environmental health and other relevant areas are the foundation of the One Health approach (4). To this end, we organized this special issue to explore the potential risks of public health from different ecological perspectives based on a variety of research methods and data sources, which might be a slight challenge for traditional studies of public health. For example, Zhao MC et al. analyzed the distribution and evolution of viruses and hosts globally (5). $\mathrm{Xu} \mathrm{M}$ et al. estimated relationship between ocean environment and infectious diarrheal disease (G). Hong $\mathrm{Z}$ et al. provided a perspective to eliminate schistosomiasis through the One Health approach ( 7 ). The findings rising from the issue highlight the necessity and importance to promote interdisciplinary research as the foundation of One Health.

doi: $10.46234 / \mathrm{ccdcw} 2022.022$

${ }^{*}$ Corresponding author: Zhongwei Jia, urchinjj@163.com.

\footnotetext{
${ }^{1}$ Department of Global Health, School of Public Health, Peking University, Beijing, China; ${ }^{2}$ Center for Intelligent Public Health, Institute for Artificial Intelligence, Peking University, Beijing, China; ${ }^{3}$ Peking University Clinical Research Institute, Beijing, China.
}

\section{REFERENCES}

1. Rubin CS. Operationalizing One Health: stone mountain and beyond. In: Mackenzie JS, Jeggo M, Daszak P, Richt JA, editors. One health: the humananimal-environment interfaces in emerging infectious diseases. Berlin, Heidelberg: Springer. 2013173 - 83. http://dx.doi.org/10.1007/82_2013_310.

2. Eurosurveillance Editorial Team. Inaugural 'one health day' organised on 3 November 2016. Eurosurveillance 2016;21(44):30386. http://dx.doi.org/10. 2807/1560-7917.ES.2016.21.44.30386.

3. Sinclair JR. Importance of a One Health approach in advancing global health security and the Sustainable Development Goals. Rev Sci Tech 2019;38(1): 145 - 54. http://dx.doi.org/10.20506/rst.38.1.2949.

4. Mackenzie JS, Jeggo M. The one health approach-why is it so important? Trop Med Infect Dis 2019;4(2):88. http://dx.doi.org/10.3390/tropicalmed 4020088.

5. Zhao MC, Chen JY, Wang Q, Lu ZH, Jia ZW. A landscape analysis on virus: based on NCBI database. China CDC Wkly 2022;4(7):120 - 5. http://dx.doi. org/10.46234/ccdcw2022.019.

6. Xu M, Cao CX, Guo HY, Chen YY, Jia ZW. Exploring the association between infectious diarrheal diseases and sea surface temperatures - coastal areas of China, 2009-2018. China CDC Wkly 2022;4(7):126 - 9. http://dx.doi.org/10.46234/ccdcw2022.023.

7. Hong Z, Li L, Zhang LJ, Wang Q; Xu J, Li SZ, Zhou XN. Elimination of schistosomiasis japonica in China: from the One Health perspective. China CDC Wkly 2022;4(7):130 - 4. http://dx.doi.org/10.46234/ccdcw2022.024. 